Larysa Petrychenko,

Doctor of Pedagogy, associate professor, first vice-rector, Kharkiv Academy of Humanities and Pedagogy,

7, Rustaveli Lane, Kharkiv, Ukraine

\title{
CURRENT STATE AND POSSIBILITIES OF FORMING HEALTHY LIFESTYLE AMONG STUDENTS OF ADOLESCENT AND YOUTH AGE UNDER CONDITIONS OF SOCIAL PROBLEMS AGGRAVATION IN UKRAINE
}

The paper presents the author's attitude to solving one of the present-day key problems - the formation of healthy lifestyle of students of adolescent and youth age. The aim of the paper is to substantiate the criterial and diagnostic basis, and to present the results of experimental study of the issue of forming healthy lifestyle among adolescents and youth studying at the teacher training college. The following methods were applied in the pedagogical study: observation of students' behaviour, conversations, questionnaires using original inventories for students and pedagogical staff, questioning according to the author's procedure. The pedagogical experiment involved 678 students obtaining education at teacher training college of Kharkiv Academy of Humanities and Pedagogy from the first to the fourth years of study, aged 15-19 years as well as 127 representatives of the teaching staff. According to the research outcomes, there is the need to intensify pedagogical staff's efforts in terms of forming healthy lifestyle among students of adolescent and youth age. These efforts should be aimed at instilling certain behaviours by means of providing the students with the information concerning importance of health, attitude towards their own and other people's health; at the formation of knowledge, abilities and skills, personal values, motives, interests related to health preservation and promotion; at the stimulation of students' activities associated with preservation of their own health.

Keywords: healthy lifestyle formation, adolescents and youth, pedagogical education, criteria for experimental study of the formation of students' healthy lifestyles.

\section{Introduction}

At the current stage of the Ukrainian society development there are some social changes having negative impact on the formation of young generation's knowledge about health preservation. As a result, the formation of a harmoniously developed, socially active and physically healthy personality takes on particular significance.

Relevance of the formation of young people's healthy lifestyles is confirmed by the results of statistical investigations performed by the Ministry of Healthcare of Ukraine, which demonstrate that tobacco smoking, drinking alcohol, taking drugs, and unsafe sexual behaviour have become quite common for comprehensive school and university students.

The formation of young people's healthy lifestyles was proclaimed as the priority area of the national policy in solving the above-mentioned problem. In particular, a number of national programmes, doctrines and legislative acts have been adopted. For example, the need for healthy lifestyle formation among children and youth is emphasised in the Article 3 of the Constitution of Ukraine, the Law of Ukraine "On Physical Culture and Sports", the Conception of the national special-purpose programme "Healthy Nation", etc.

The issues of health and healthy lifestyle of young generation as well as conditions of their optimisation were investigated by philosophers, medical professionals, psychologists, teachers, and social care teachers. Theoretical and methodological basis for health saving was provided by the works of H. Zdravomyslov, N. Smirnov, P. Sushchenko et al., the issues of forming personality's healthy lifestyle from the medical perspective were covered in the works of M. Amosov, V. Artamonov, P. Leontyev, V. Yazlovetskyi et al. Psycho-pedagogical aspects of forming a healthy lifestyle among children and youth were considered by T. Boichenko, R. Vainola, H. Holoborodko, A. Kapska, M. Kobrynskyi, T. Krutsevych, S. Lapaienko, S. Omelchenko, V. Orzhekhovska, Yu. Pokholinchuk, V. Radul, S. Svyrydenko, M. Solopchuk et al.

Having analysed the research works, it can be concluded that, despite a great number of studies dedicated to the saving of younger generation's health, the issues of forming students' healthy lifestyles under conditions of social problems aggravation in Ukraine should be investigated more thoroughly.

Consequently, the paper aims to substantiate the criterial and diagnostic basis and to present the results of experimental study of the issue of forming healthy lifestyle among adolescents and youth attending the teacher training college.

\section{Research methods}

The following methods and diagnostic tools were used in the pedagogical research: observation of students' behaviour, conversations, questionnaires using original inventories for students ("I and my health: check yourself", "Needs in the sphere of health saving", "What do I know about a healthy lifestyle?") and pedagogical staff "Assessment of health-saving environment of and educational institution"; questioning according to the author's procedure "Self-assessment of the attitude towards health"; review of documents (studying plans and reports 
on the work of student groups' mentors, records in emergency events journal of the dormitory, reporting documents of social and psychological services of the educational institution, etc.).

\section{Discussion}

The most important indicators of education quality are employers' satisfaction with training and education; the degree of various social partners' participation in the development and implementation of educational institution's policy and the system of co-management; subjective and objective image of an educational institution; a mission reflecting a long-term goal; graduates' enrolment into higher educational institutions (for comprehensive educational institutions) and their further employment (for vocational educational institutions) [3, p. 11]. Obviously, it depends on the state of health of all the subjects of the educational process.

In contemporary science, theoretical and practical issues of forming a healthy lifestyle are being studied and developed. Based on the research works' analysis [2, p. 8], the process of forming healthy lifestyle in adolescents and youth is defined as a set of approaches, methods, means, techniques, and algorithms of creating health- saving environment at the educational institution, where students' professional development is taking place, by means of providing them with knowledge about health and its maintenance, health-saving abilities and skills, health-related values; consolidating behavioural strategies concerning preservation of their own and other people's health. Health-saving environment is considered as the one, which is active in relation to student's health, provides its maintenance and contributes to the formation of knowledge about health as a value, facilitates motivation for keeping a healthy lifestyle, increases responsibility for student's own and other people's health.

Against this background, it is worth noting that the process under study is quite complicated and multifaceted; that is why, for objective study of the formation of healthy lifestyle among adolescents and youth at the educational institution, it is reasonable to substantiate corresponding criteria and levels. For example, theoretical analysis $[1 ; 2 ; 5 ; 6]$ made it possible to determine criteria and corresponding characteristics of the level of students' healthy lifestyle formation, which are represented in the Table 1 .

Criteria, indicators, diagnostic techniques of the level of healthy lifestyle formation among students of adolescent and youth age

\begin{tabular}{|c|c|c|c|}
\hline No. & Criterion & Characteristics & Diagnostic techniques \\
\hline 1 & ن. & $\begin{array}{l}\text { Knowledge of basic principles and characteristics of a } \\
\text { healthy lifestyle } \\
\text { Forming needs and interest in deepening knowledge } \\
\text { concerning a healthy lifestyle } \\
\text { Adolescents' and youth's knowledge of the issues of } \\
\text { preserving their own health (physical, mental, social) }\end{array}$ & $\begin{array}{l}\text { Inventory "What do I know about a } \\
\text { healthy lifestyle?" }\end{array}$ \\
\hline 2 & 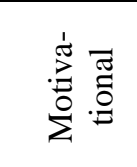 & $\begin{array}{l}\text { Moral and ethical motivation for following the rules } \\
\text { of a healthy lifestyle } \\
\text { Self-assessment of one's own attitude towards } \\
\text { health }\end{array}$ & $\begin{array}{l}\text { Inventory "Needs in the sphere of health } \\
\text { saving"; } \\
\text { Questionnaire "Self-assessment of the } \\
\text { attitude towards health" }\end{array}$ \\
\hline 3 & 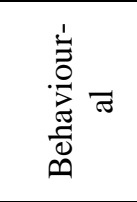 & $\begin{array}{l}\text { Keeping healthy lifestyle conditions by students } \\
\text { Abilities and skills of keeping a healthy lifestyle } \\
\text { and correct behaviour } \\
\text { Presence/absence of bad health habits and } \\
\text { knowledge of their prevention strategies }\end{array}$ & $\begin{array}{l}\text { Inventory "I and my health: check your- } \\
\text { self" }\end{array}$ \\
\hline
\end{tabular}

Table 1.

In the process of researching the issue of forming students' healthy lifestyles, we have distinguished and characterised the levels of healthy lifestyle formation:

the high level is characterised by knowledge about a healthy lifestyle, its components, willing to keep a healthy lifestyle and be healthy, following the rules of a healthy lifestyle (day regimen and resting time rules, avoiding taking narcotic substances, drinking alcohol and tobacco smoking, keeping proper dietary regimen, physical activity);

the medium level is peculiar to people who do not have a comprehensive idea about a healthy lifestyle, do not follow its rules, principles and norms to the full;

the low level is peculiar to people with one or several psychosomatic disorders, whose lifestyle cannot Science and Education, 2017, Issue 6 be considered healthy; they need socio-pedagogical help and support.

The diagnostic work was carried out during 2016-2017 academic year at the college belonging to the Public institution "Kharkiv Academy of Humanities and Pedagogy" of Kharkov Regional Council, where future specialists are trained in 5 specialities: Primary Education, Preschool Education, Musical Art*, Physical Education*, Social Pedagogy / Social Work. The experiment involved 678 students obtaining all of the above-mentioned specialities from the first to the fourth years of study, aged 15-19 years as well as 127 representatives of the teaching staff.

Senior adolescents (15-16 years) and young adults (17-19 years) have been chosen as study participants, as long as this age the turning period in socio-pedagogical 
aspect. A personality may acquire some bad habits or other antisocial new formations in his/her behaviour; a person becomes especially sensitive to unfavourable factors of the environment.

The purpose of the diagnostic work was studying the formation of a healthy lifestyle among students of adolescent and youth age as well as peculiarities of healthsaving environment of the educational institution.

The diagnostics included two stages: diagnostic assessment of the teaching staff (student groups' mentors, psychologists, teachers) and diagnostic assessment of adolescents and youth.

Let us consider every stage in details. 127 persons (including 94 teachers, 30 mentors, 2 psychologists and one social care teacher) took part in the questioning. Particular attention was paid to the questioning of student groups' mentors, who, according to S. Omelchenko, are the key subjects in the formation of a healthy lifestyle among adolescents and young adults attending educational institutions [3, p. 40-45]. The surveyed were supposed to give written detailed answers to the questions included in the inventory titled "Assessment of health-saving environment of an educational institution", which consisted of 5 open-end questions and was anonymous.

Results of questioning revealed the necessity to intensify the work on the formation of young people's healthy lifestyle. According to the questionnaire, 38.4\% of the surveyed pointed out at the necessity to increase the level of preparedness for carrying out such kind of work, especially under conditions of the spreading of dangerous infectious diseases among children and youth.

When asked if it was promising to implement innovative means of forming a healthy lifestyle among adolescents at the educational institution, $76.8 \%$ of the surveyed gave positive replies. In their opinion, such activity will be effective and have positive impact on adolescents' behaviours, contribute to the formation of responsible attitude towards their own health and motivation for keeping a healthy lifestyle. Teachers and other member of the pedagogical staff find it reasonable to use active forms of work, including interactive techniques that initiate participation of adolescents and young adults in interactive theatres, work of youth lecturing groups, facilitate the development of correct behaviours, and help students adapt in various circumstances.

To assess the level of students' knowledge about a healthy lifestyle (the cognitive criterion), we used the inventory "What do I know about a healthy lifestyle?"; to assess the level of the motivation criterion development - the inventory "What prevents me from keeping a healthy lifestyle?"; the behavioural one - "Can you keep a healthy lifestyle?".

The inventory "What do I know about a healthy lifestyle?" included 8 questions. It was anonymous, which enabled us to receive unbiased information. Average data of the questioning are represented in the Table 2.

Table 2.

Average data of students' questioning using the inventory "What do I know about a healthy lifestyle?"

\begin{tabular}{|l|l|l|}
\hline \multicolumn{1}{|c|}{ Adolescents } & \multicolumn{1}{c|}{ Youth } \\
\hline Levels of respondents' answers distribution & $27 \%$ & $10.3 \%$ \\
\hline Medium & $66.3 \%$ & $73 \%$ \\
\hline Low & $6.7 \%$ & $6.7 \%$ \\
\hline
\end{tabular}

Results of the questioning demonstrate that $67.8 \%$ of the students cannot give a well-grounded definition to the concept "a healthy lifestyle" and distinguish its characteristic attributes clearly. What is more, the respondents (especially of adolescent age) are not able to characterise harmful effects of smoking, drinking alcohol and taking narcotic substances on human body.

Analysis of the questioning results makes it possible to state that almost a third of the surveyed do not consider it necessary to keep a healthy lifestyle, get knowledge about it, take physical exercises and have active attitude to life. Furthermore, the respondents leave open the possibility to take harmful substances, substantiating it with the fact that they are worth a try.
Assessment of adolescents' and young people's motivation for keeping a healthy lifestyle (the motivational criterion) was conducted with the help of the inventory "What prevents me from keeping a healthy lifestyle?". The purpose of the assessment was to identify factors that prevent students from keeping a healthy lifestyle. The inventory consisted of 2 parts: the first one included 4 general questions and the second one - a series of questions aimed at identifying barriers that prevent form keeping a healthy lifestyle. The questionnaire consisted of 12 statements with the suggested comments "always", "often", "sometimes", "rarely", "never". The results are represented in the Table 3.

Table 3.

Characteristics of the levels of hindrances preventing adolescents and youth from keeping a healthy lifestyle

\begin{tabular}{|c|c|c|c|}
\hline Levels of hindrances & No of scores & No of adolescents & No of young adults \\
\hline High level & $12-18$ & $13.6 \%$ & $6.8 \%$ \\
\hline Medium level & $19-34$ & $27 \%$ & $33.7 \%$ \\
\hline Low level & $35-60$ & $59.4 \%$ & $59.4 \%$ \\
\hline
\end{tabular}


The results obtained demonstrate the fact that $59.4 \%$ of the surveyed had the low level of hindrances preventing them from keeping a healthy lifestyle, i.e. adolescents and youth are able to overcome insignificant difficulties preventing them from keeping a healthy lifestyle; almost a third of the surveyed noted the medium level of hindrances, which demonstrates that the students are not able to solve some of problems related to a healthy lifestyle and need help on the part of their equals in age, friends as well as adults - parents, teachers, psychologists, social care teachers, and other specialists. It is worth noting that $6.8 \%$ of the surveyed adolescents and $13.6 \%$ of the young people had the high level of hindrances, which makes it possible to state that they have significant problems associated with keeping a healthy lifestyle.

Based on the performed diagnostics, we can conclude that in most cases there are no reasons why the surveyed cannot keep a healthy lifestyle (physical condition, domestic problems, bad influence of friends, etc.); it means that keeping a healthy lifestyle depends completely on them, their willing and orientation at health maintenance. That is why, it is necessary to educate corresponding attitude in younger generation, provide every adolescent and young person with the information about responsibility for their own lives and health.

The questionnaire "Can you keep a healthy lifestyle?" was targeted at identifying the levels of the students' behavioural orientations related to keeping a healthy lifestyle. Most of the surveyed (59.6\%) gave positive answers to the question; negative answers were given by $33.7 \%$ of the surveyed, which means that they cannot keep a healthy lifestyle because of poor knowledge of health-related issues. Only $6.7 \%$ of the surveyed were not ready to give an answer.

Further investigation, including observation of adolescents' lifestyles, has made it possible to determine that $13.4 \%$ of the surveyed keep a healthy lifestyle, they have health-saving skills and do health-improving sports. $40.4 \%$ of the surveyed have lifestyle, which is close to healthy, but still they have some opportunities for improving efficiency by means of more appropriate organisation of their work depending on the peculiarities of their bodies. The rest of the surveyed - almost a half of them - live an unhealthy lifestyle and need help of the specialists: supervising teachers, social care teachers, psychologists, medical workers, etc.

Also, the survey shows that $53.8 \%$ of the respondents have a passive rest, particularly during the recess period, which demonstrates impropriety of their lifestyles. It may be explained by the fact that passive rest is usually associated with Internet-addiction, which has become one the most serious problems of modern young people.

It is worth noting that $66.3 \%$ of the surveyed keep improper sleeping hours and "rest depending on their mood or finishing the work". This factor is considered to be negative, especially at adolescent age, when it is particularly important to go to bed at one and the same time for keeping vitality. Healthy sleep is an important component of a healthy lifestyle.

The results of the questionnaire demonstrate unhealthy diet of adolescents and young people: almost $40 \%$ of the students do not have breakfast at home, while breakfast provides people, especially the young ones who study, with the important reserve of energy.

Generally speaking, it can be stated that a considerable part of the surveyed have the low level of knowledge, motivation and skills related to a healthy lifestyle, which shows the necessity to develop and implement a complex of innovative means of socio-pedagogical work intended for the formation of students' healthy lifestyles. The most significant health-related problems of adolescents and youth are the following: moderate level of drinking alcohol and high level of nicotine addiction. This fact actualises the issues of the development, implementation and experimental testing of the effectiveness of education means targeted at the formation of students' healthy lifestyles.

In this case, it should be taken into account that future teacher's professional culture, which is the ultimate goal of higher education and is a unique phenomenon of pedagogical reality, as long as it is acquired in the process of professional training and pedagogical activities as a set of knowledge, abilities and skills of a teacher, his/her professional competence, humanistic system of professional and personal values, creative approaches to teacher's work, includes health-saving component. Such a component is a specific source of teacher's work, means and tool of pedagogical influence, therefore it is to be formed in future pedagogical staff members (students of teacher training college) in the process of professional training under condition of mutually active, didactically rich, innovative, effective interaction with pedagogical staff of the educational institution.

It is also worth noting that the health-saving component must be fully reflected in future teachers' professional training. Considering the scope of profession-oriented learning material (the information reflecting professional focus of future teacher's work) included in the content of student training, the purposeful process of the formation of students' professional culture requires optimal use of time-content resources facilitating the acquisition of the information related to health saving.

As demonstrated by generalised analysis of the curricula for training future teachers, such a comprehensive mission of the specialists determines corresponding diversity of academic disciplines included in the content of their training. In particular, some aspects of keeping a healthy lifestyle related to history of culturology can be outlined while teaching Philosophy, Culturology, Social Studies, History of Ukraine, which are compulsory for training future teachers obtaining Bachelor's degrees and included to the humanities and socio-economic disciplines. Fundamentals of medical knowledge, environmental and information culture, etc. are introduced while teaching natural sciences. 
The disciplines related to future profession and practical training provide the students with psychopedagogical knowledge about a healthy lifestyle. Optional part of the curriculum must include profession-related disciplines chosen by the educational institution and students, which provide additional theoretical, practical and instructional pedagogical training in terms of keeping a healthy lifestyle. Analysis of professional training at the teacher training college demonstrates that it is implemented due to a considerable amount of hours allocated for learning psycho-pedagogical disciplines.

Such orientation of the content of training, in our opinion, will provide transition of the informational component of education to the knowledge-based one - future teachers' acquisition of fundamental knowledge of psychology and pedagogy, which will become the basis for the formation of a healthy lifestyle, acquisition of corresponding abilities, development of a future teacher's personality, gaining positive practical pedagogical experience in health-saving activities.

Enrichment of the content of future teacher's professional training with additional information, introduction of new topics and special courses covering topical issues of keeping a healthy lifestyle are undoubtedly important for the formation of a healthy lifestyle as a component of future teachers' pedagogical culture. However, the quality of such information - approaching it to the issues of future professional activities, strengthening the interrelation between the content of professional pedagogical disciplines and health-saving experience gained by the students - will be more influential for increasing the level of healthy lifestyle formation.

\section{Conclusions}

In order to study the state of adolescents' and

\section{REFERENCES}

1. Vasylenko, O. M. (2015). Zmist pidhotovky maibutnikh sotsialnykh pedahohiv do zastosuvannia zdoroviazberezhuvalnykh tekhnolohii $\mathrm{u}$ roboti $\mathrm{z}$ ditmy ta moloddiu [The content of preparing future social care teachers for using health-saving technology in work with children and youth]. Pedahohika ta psykholohiia: zbirnyk naukovykh prats - Pedagogy and psychology: Collection of scientific papers, 48, 16-24. I. F. Prokopenko (Ed.). Kharkiv: Vyd-vo TOV "Shchedra sadyba plius" [in Ukrainian].

2. Vasylenko, O. M. (2016). Pidhotovka maibutnikh sotsialnykh pedahohiv do vykorystannia zdoroviazberezhuvalnykh tekhnolohii u roboti $\mathrm{z}$ doshkilnykamy [Preparing future social care teachers for using health-saving technology when working with preschool children]. Extended abstract of candidate's thesis. Sloviansk [in Ukrainian].

3. Omelchenko, S. O. (2007). Kurator akademichnoi hrupy - dominuiucha fihura u protsesi formuvannia zdorovoho sposobu zhyttia studentskoi molodi [Student group curator is a key person in the formation of students' healthy lifestyle]. Humanizatsiia navchalnovykhovnoho protsesu: zbirnyk naukovykh prats - Educational process humanisation: Collection of scientific youth's healthy lifestyles formation, we have substantiated the following criteria: the cognitive one, which is determined by the level of knowledge about health, a healthy lifestyle, its components and essence, factors of impact on health, risks of bad health habits, acquisition of knowledge about healthy lifestyle; the motivational one determines the ability to be guided by universal human spiritual values, including health as a value, moral and ethical motivation for following the rules of a healthy lifestyle, concern about environment condition and population sickness level; the behavioural one is characterised by abilities and skills related to a healthy lifestyle and proper behaviour, keeping them in everyday life, preventing bad health habits or giving them up.

Based on the study conducted with the students of the teacher training college according to the abovementioned criteria, it can be concluded that there is the need to intensify pedagogical staff's efforts in terms of forming healthy lifestyles among the students of adolescent and youth age. These efforts, including social care teacher's preventive work in the framework of primary, secondary or tertiary prevention, should be aimed at instilling certain behaviours by means of providing the students with the information concerning importance of health, attitude towards their own and other people's health; at the formation of knowledge, abilities and skills, personal values, motives, interests related to preservation and promotion of health; at the stimulation of the students' activities associated with preservation of their own health.

In our opinion, further detailed development and implementation of innovative forms and methods of forming future teachers' healthy lifestyles is a promising area of research in the context of the issues studied.

papers, 34, 40-45. Sloviansk: Vyd. tsentr SDPU [in Ukrainian].

4. Petrychenko, L. O. (2007). Pidhotovka maibutnoho vchytelia pochatkovoi shkoly do innovatsiinoi diialnosti $\mathrm{v}$ pozaaudytornii roboti [Preparing future primary school teachers for innovation activities in out-of-class work]. Extended abstract of candidate's thesis. Kirovohrad [in Ukrainian].

5. Rasskazova, O. I. (2009). Sotsialnopedahohichnyi pidkhid do zberezhennia psykhichnoho zdorovia molodi [Socio-pedagogical approach to preserving young people's mental health]. Spryiannia zdoroviu ditei ta molodi: teoretyko-metodychni aspekty - Promotion of children's and youth's health: theoretical and methodological aspects: Proceeding of the $4^{\text {th }}$ International socio-pedagogical conference. (pp. 348-355) [in Ukrainian].

6. Kharchenko, S. Ya. (2006). Sotsializatsiia ditei ta molodi $v$ protsesi sotsialno-pedahohichnoi diialnosti: teoriia i praktyka [Socialisation of children and youth in socio-pedagogical activities: theory and practice]. Luhansk: Alma-mater [in Ukrainian]. 


\section{ЛІТЕРАТУРА}

1. Василенко О. М. Зміст підготовки майбутніх соціальних педагогів до застосування здоров'язбережувальних технологій у роботі здітьми та молоддю / О. М. Василенко // Педагогіка та психологія : збірник наукових праць / за заг. ред. академіка I. Ф. Прокопенка. - Харків : Вид-во ТОВ «Щедра садиба плюс», 2015. - Вип. 48. - С. 16-24.

2. Василенко О. М. Підготовка майбутніх соціальних педагогів до використання здоров'язбережувальних технологій у роботі 3 дошкільниками: автореф. дис. на здобуття наук. ступеня канд. пед. наук : спец. 13.00.05 «Соціальна педагогіка»/ Олена Миколаївна Василенко; Держ. вищ. навч. закл. «Донбас. держ. пед. ун-т». Слов'янськ, 2016. - 20 с.

3. Омельченко С. О. Куратор академічної групи - домінуюча фігура у процесі формування здорового способу життя студентської молоді / С. О. Омельченко // Гуманізація навчально-виховного процесу : зб. наук. пр. - Вип. XXXIV. - Слов'янськ : Вид. центр СДПУ, 2007. - С. 40-45.

4. Петриченко Л. О. Підготовка майбутнього вчителя початкової школи до інноваційної діяльності в позааудиторній роботі : автореф. дис. на здобуття наук. ступеня канд. пед. наук: спец. 13.00.04 «Теорія і методика професійної освіти» / Л.О.Петриченко ; Кіровоградський державний пед. університет імені Володимира Винниченка. - Кіровоград, 2007. - 20 с.

5. Рассказова О. І. Соціально-педагогічний підхід до збереження психічного здоров'я молоді/ О. І. Рассказова // Сприяння здоров’ю дітей та молоді : теоретико-методичні аспекти: матеріали IV Міжнародної соціально-педагогічної конференції (Луцьк, 2009). - Луцьк, 2009. - С. 348-355.

6. Харченко С. Я. Соціалізація дітей та молоді в процесі соціально-педагогічної діяльності : теорія i практика : Монографія. - Луганськ : Альма-матер, 2006. $-320 \mathrm{c}$.

Лариса Олексіӥвна Петриченко,

дочент, доктор педагогічних наук, перший проректор, Харківська гуманітарно-педагогічна академія, пров. Руставелі, 7, м. Харків, Україна

\section{СУЧАСНИЙ СТАН І ПЕРСПЕКТИВИ ФОРМУВАННЯ ЗДОРОВОГО СПОСОБУ ЖИТТЯ ПІДЛІТКІВ І МОЛОДІ, ЯКІ НАВЧАЮТЬСЯ, В УМОВАХ ЗАГОСТРЕННЯ СОЦІАЛЬНИХ ПРОБЛЕМ В УКРАЇНІ}

У статті репрезентовано авторську позицію щодо розв'язання гострої проблеми сьогодення - формування здорового способу життя підлітків і молоді, які навчаються. Актуальність проблеми формування здорового способу життя молоді підтверджується результатами статистичних досліджень Міністерства охорони здоров’я України, за даними якого поширеним явищем серед учнів загальноосвітніх навчальних закладів і студентської молоді стали тютюнопаління, вживання алкогольних напоїв і наркотиків, а також небезпечна статева поведінка. Метою статті є обгрунтування критеріально-діагностичної бази й оприлюднення результатів експериментального вивчення проблеми формування здорового способу життя студентів старшого підліткового та молодіжного віку в умовах педагогічного коледжу. Під час проведення педагогічного дослідження використовувалися такі методи: спостереження за поведінкою студентів, бесіди, анкетування за авторськими анкетами для студентів і педагогічних працівників, опитування за авторською методикою. Діагностична робота проводилась у 2016-2017 н. р. у Харківському коледжі Комунального закладу «Харківська гуманітарно-педагогічна академія» Харківської обласної ради. В експерименті брали участь студенти, які навчаються за спеціальностями «Початкова освіта», «Дошкільна освіта», «Музичне мистецтво*», «Фізичне виховання*», «Соціальна педагогіка / Соціальна робота» 31 по 4 курс, віком 15-19 років, загальною кількістю 678 осіб, а також 127 осіб педагогічних працівників. Для вивчення стану формування здорового способу життя підлітків і молоді, які навчаються, було обгрунтовано критерії: когнітивний, мотиваційний та поведінковий. На підставі дослідження визначено необхідність посилення роботи педагогічного колективу з формування здорового способу життя підлітків і молоді, які навчаються, спрямованої на прищеплення відповідної поведінки через надання інформації для усвідомлення цінності здоров'я та ставлення до власного здоров'я і здоров'я оточуючих, формування системи знань, умінь та навичок, особистісних цінностей, мотивів, інтересів щодо збереження та зміцнення здоров'я, стимулювання до активної діяльності особистості зі збереження власного здоров'я.

Ключові слова: формування здорового способу життя, підлітки та молодь, педагогічна освіта, критерії експериментального вивчення проблеми формування здорового способу життя студентів.

Submitted on May, 6, 2017 